удк 657.375

\title{
ОПТИМІЗАЦІЯ ДІЯЛЬНОСТІ СТРАХОВОГО СЕКТОРУ ЧЕРЕЗ ВПРОВАДЖЕННЯ ЕФЕКТИВНОЇ СИСТЕМИ ВНУТРІШНЬОГО АУДИТУ
}

\section{OPTIMIZATION OF THE INSURANCE SECTOR THROUGH THE INTRODUCTION OF AN EFFECTIVE SYSTEM OF INTERNAL AUDIT}

\author{
Френзель Валерія Юріївна \\ студент, \\ Харківський національний університет імені В.Н. Каразіна \\ ORCID: https://orcid.org/0000-0002-6052-2113 \\ Слюніна Тетяна Леонідівна \\ кандидат економічних наук, доцент, \\ Харківський національний університет імені В.Н. Каразіна \\ ORCID: https://orcid.org/0000-0002-1398-1210
}

Frenzel Valeriia, Slunina Tatyana

V.N. Karazin Kharkiv National University

\begin{abstract}
В дослідженні пропонується визначення місця та ролі внутрішнього аудиту в системі ефективного управління страховою компанією для використання потенціалу страхових компаній і створення позитивного впливу на фрінансовий ринок України. Страхова галузь розглядається як невід'ємна частина ринкової економіки в аспекті акумуляції вільних коштів споживачів страхового продукту та створенні фрінансового резерву від непередбачуваних подій. Автор розглядає внутрішній аудит страхових компаній як специорічний напрям аудиторської діяльності, оскільки фрінансова неспроможність страхової компанії стосується інтересів значної кількості осіб - страхувальників і застрахованих. В дослідженні пропонуються шляхи підвищення ефективності страхової діяльності в контексті цифровізації галузі та впровадженні новітніх технологій аналізу даних.
\end{abstract}

Ключові слова: страхові компанії, фрінансова звітність, внутрішній аудит, регулювання, страхування, страхова премія.

В исследовании предлагается определение места и роли внутреннего ау-дита в системе эфффективного управления страховой компанией для использования потенциала страховых компаний и создания положительного влияния на финансовый рынок Украины. Страховая отрасль рассматривается как неотъемлемая часть рыночной экономики в аспекте аккумуляции свободных средств потребителей страхового продукта и создании фринансового резерва от непредсказуемых событий. Автор рассматривает внутренний аудит страховых компаний как специфическое направление аудиторской деятельности, поскольку финансовая несостоятельность страховой компании касается интересов значительного количества лиц - страхователей и застрахованных. В исследовании предлагаются пути повышения эфффективности страховой деятельности в контексте цифровизации области и внедрении новейших технологий анализа данных.

Ключевые слова: страховые компании, фринансовая отчетность, внутренний аудит, регулирование, страхование, страховая премия.

The study proposes the definition of the role and place of internal audit in the system of effective management of the insurance company to use the potential of insurance companies and the creation of a positive impact on the financial market of Ukraine. The insurance industry is considered as an integral part of the market economy in the aspect of accumulation of free funds of insurance product consumers and creation of financial reserve from unpredictable events. Insurance is one of the key activities in a globalized financial and economic environment. The insurance industry significantly affects the economy by transforming accumulated savings into effective investments. Insurance allows to level losses, ensure financial stability and development of commercial activity in the country, which leads to economic growth. Thus, insurance plays a crucial role in the sustainable growth of the economy. Today the development of insurance market is restrained by a number of factors, in particular some insurance compa- 
nies have problems with solvency and liquidity, there is no clear business model, the level of corporate governance and risk management leaves much to be desired. The author considers the internal audit of insurance companies as a specific area of audit activity, since the financial insolvency of the insurance company concerns the interests of a significant number of persons - policyholders and insured. Insurance companies need to implement an effective system of internal control of solvency violation risks and, even more so, of liquidity violation risks, which will facilitate their neutralization at an early stage. The successful functioning of an insurance organization is impossible without effective control, which allows the management of the company to receive necessary and reliable information for making management decisions. In order to assess the financial stability of the insurance organization, the internal control system should carry out continuous monitoring of the compliance of parameters and requirements, on the basis of which the model of internal control and audit system of insurance organizations, aimed at preventive diagnosis of the risks of the insurer was developed. The study proposes ways to improve the efficiency of insurance activities in the context of the digitalization of the field and the introduction of the latest data analysis technologies.

Keywords: insurance companies, financial reporting, internal audit, regulation, insurance, insurance premium.

Постановка проблеми. Страхування $€$ одним з ключових видів діяльності в умовах глобалізації фрінансового та економічного середовища. Страхова галузь значно впливає на економіку шляхом трансорормації накопичених заощаджень в ефрективні інвестиції. Страхування дозволяє нівелювати збитки, забезпечити фрінансову стабільність і розвиток комерційної діяльності в країні, що призводить до економічного зростання. Таким чином, страхування відіграє вирішальну роль в стійкому зростанні економіки. На сьогоднішній день розвиток страхового ринку стримує кілька чинників, зокрема, у низки страхових компаній наявні проблеми з платоспроможністю і ліквідністю, відсутня чітка бізнес-модель, рівень корпоративного управління і ризик-менеджменту залишають бажати кращого. Однією з основних цілей будь-який бізнес-одиниці $€$ досягнення більш високої прибутковості, проте страхові компанії мають багато особливостей, відмінних від звичайної підприємницької діяльності. їх продуктами $€$ ризики, які $€$ невидимими і несподіваними. Існує зворотний бухгалтерський цикл, коли страхові компанії спочатку збирають премії, а після настання страхових випадків виплачують компенсації. Незадіяний капітал страхових компаній зазвичай інвестується в фрінансову діяльність, бізнес-процеси є складними правовими відносинами, а масштаби їх діяльності широкі і геограсрічно розосереджені. Специфріка страхових компаній визначає зміст, методи і процедури внутрішнього аудиту фрінансової звітності. Розвиток сталого та надійного страхового ринку вимагає значних зусиль як з боку регулятора, так і з боку учасників страхового ринку. Збалансована та комплексна модель внутрішнього аудиту здатна вивести страхову галузь зі стану стагнації. Дане дослідження проводиться для вирішення можливих шляхів оптимізації процесу внутрішнього аудиту страхових компаній.
Аналіз останніх досліджень і публікацій. Проблему створення ефективної системи внутрішнього аудиту страхових компаній почали розглядати у своїх роботах такі науковці як Гаманкова О.О. «Облік і аудит у страхових організаціях»; М.Є. Добрусіна, Ж.Н. Жуковська «Бухгалтерський облік, оподаткування і аудит страхових організацій», Кундузова К.І., Хабіжонов С.К «Аудит в страхових організаціях: особливості і проблеми»; Войнова $€$. «Ринок страхових послуг і його позиціонування серед провідних страхових ринків світу». Започатковані дослідження свідчать про недостатній рівень вивчення проблеми проведення якісного аудиту в страхових компаніях і вимагають подальших розробок.

Виклад основного матеріалу дослідження. Протягом 2013-2018 років великі страхові групи, зокрема AXA, SEB, AEGON, AIG i HDI, пішли з України, в тому числі через недобросовісну конкуренцію на ринку. Актуальність проблем в страхових компаніях обумовлена насамперед відсутністю сучасного комплексного підходу бухгалтерського обліку та внутрішнього аудиту досліджуваних операцій. Створюючи впевненість для інших, страхова індустрія змушена фрункціонувати в дуже невизначених реаліях. Швидкі економічні, соціальні, політичні та екологічні зміни, що відбуваються в усьому світі, призводять до значних змін в ризиках, від яких страховий сектор забезпечує захист. Вищевказані системні проблеми на страховому ринку України обумовлені, перш за все, недосконалістю правового регулювання, а також недосконалою регуляторною політикою і відсутністю належного нагляду за ії проведенням. Тому розвиток сталого та надійного страхового ринку вимагає значних зусиль як з боку регулятора, так і з боку учасників страхового ринку. Збалансована та комплексна модель внутрішнього аудиту здатна вивести страхову галузь зі стану стагнації. 
Через посилення нормативів оцінки платоспроможності страхових компаній у відповідності 3 Постановою Нацкомфрінпослуг № 850 від 2018 року відбулося значне скорочення кількості страхових компаній на ринку України. Страховий сектор підлягає чищенню на кшталт банківського, задля досягнення прозорості та відповідності міжнародним стандартам регулювання. Станом на 28 травня 2021 року в Державному реєстрі фрінансових установ зареєстровано 208 страхових компаній (рис. 1), з яких 20 надають послуги зі страхування життя (або страхування "life"), а 188 здійснюють види страхування інші, ніж страхування життя (загальне страхування / страхування "non-life"). Кількість страхових компаній з 2000-х років відносно не змінювалася, але після кризи 2008-2009 років почала скорочуватися. Порівняно 32018 роком з ринку страхування пішли 73 компанії через те, що не займалися страховою діяльністю більше 6 місяців або вирішили відмовитися (відкликати) ліцензії [1].

Регулювання ринку страхових компаній покладено на Національний банк України (НБУ), в березні 2021 року НБУ складено
46 актів про порушення страховиками нормативів і сім актів за ненадання компаніями звітності регулятору. За підсумками розгляду 20 компаній зобов'язали усунути порушення і тимчасово зупинили ліцензії 17 компаній (7 - за неподання звітності, 10 - за порушення нормативів, в тому числі одного страховика життя і чотирьох ліцензіатів ОСАГО).

У 2020 році епідемія COVID-19 вплинула на страховий ринок, однак по-мірно: продовжилася тенденція до зростання обсягу страхових премій: їх кількість збільшилася на 12\%. Зросли і виплати страхових відшкодувань - на 9\%. Продовжується тенденція до скорочення кількості страховиків, насамперед через добровільну відмову від ліцензій і відходу з ринку за власною ініціативою. Кілька страховиків пішли з ринку добровільно після того, як НБУ склав акти про порушення вимог законодавства [2].

На скорочення кількості страхових компаній значний вплив здійснюють недосконалості у регуляторній політиці, а саме: відсутність системного і послі-довного регулювання страхового сектору, що призводить до хаотичного розвитку страхового ринку; недосконалість

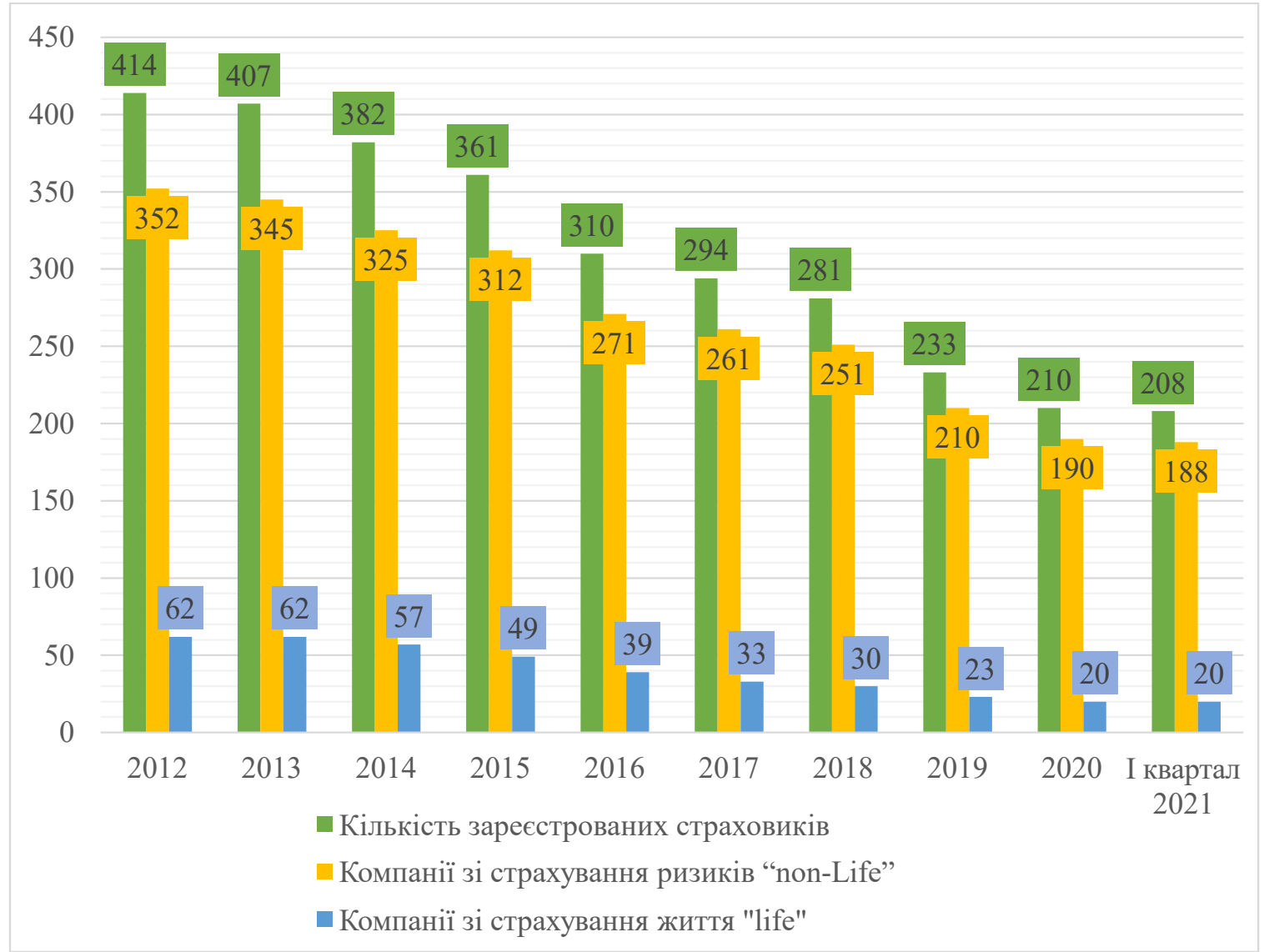

Рис. 1. Динаміка кількості страхових компаній в Україні протягом 2012-2021 рр. Джерело: [1; 2] 
існуючої нормативно-правової бази, що регулює розвиток страхової галузі; відсутність унісрікованих стандартів оцінки фрінансового стану, платоспроможності, системи управління ризиками страховика, а також порядку розкриття інфоомації.

Складнощі в стабільному фрункціонуванні страхового сектору виходять за рамки невідповідності нормативам. До числа фракторів, що негативно впливають на ринок страхування в Україні належать недостатньо ефрективна система управління ризиками і низька якість управління, що зустрічається в деяких СК.

На сьогодні страховий ринок демонструє закритий характер діяльності більшості компаній, слабкий сектор страхування життя і неготовність до впровадження пенсійного та медичного страхування. На ринку немає достатньо якісних систем обліку, нагляду і розкриття інфрормації про страхову діяльність. Це відображає відсутність системності в розвитку ринку і недостатність цілеспрямованої державної політики.

Сьогоденна система оцінки платоспроможності українських страхових компаній $є$ обмеженою адаптацією Solvency I - європейської системи оцінки платоспроможності. Через це регулятор НБУ не має можливості вчасно реагувати на потенційні проблеми та ризики страховиків (наприклад, недотримання достатнього рівня платоспроможності). Ці складнощі спотворюють картину страхового ринку України. Через недостатнє регулювання діяльності страхових компаній, у кінцевого споживача занадто мало гарантій того, що страховик виконає свої зобов'язання повністю, і адекватно оцінить страховий випадок, якщо він настане. Все це дуже підриває рівень довіри до молодого українського ринку страхування.

Для приведення українського ринку страхових послуг у відповідність 3 європейськими стандартами до 2023 року має бути розроблена актуальна законодавча база для комплексної імплементації актів європейського законодавства в частині розвитку фрінансового сектору. Серед ключових нововведень має бути вдосконалення вимог закону «Про страхування» до фрінансового стану, платоспроможності, системи управління ризиками страховика, а також порядку розкриття інфрормації. Станом на 17 червня 2021 року Верхова Рада України прийняла в першому читанні Закон України «Про страхування» № 5315, який містить ключові вимоги законодавства $€ C$ та стандарти Міжнародної асоціації органів страхового нагляду (IAIS), до яких має наблизитися Україна.
Впровадження єдиних стандартів страхування $€$ дуже непростим затяжним процесом. Навіть на прикладі Європейського досвіду, впровадження Директиви ЄC Solvency II почалося з 2009 року і остаточно вступило в силу лише в січні 2016 р. Метою Директиви Solvency II $€$ встановлення єдиної системи регулювання за допомогою унісрікованих стандартів управління ризиками, забезпечення достатньої кількості капіталу страхового захисту, прозорості та зіставності фрінансової звітності. Крім директиви Solvency II, незабаром з'явиться ще один стандарт, який також кардинально змінить стан справ в сорері страхування - МСФ3 17 (раніше - МСФ3 4, фраза II), який підготувала Рада з Міжнародних стандартів фрінансової звітності. Мета МСФ3 17 - надавати більш прозору і порівнянну інорормацію, що удосконалить механізми фрінансової звітності [4].

Стандарт МСФЗ 17 розроблений для забезпечення послідовного і принципового обліку договорів страхування. Новий стандарт передбачає оцінку страхових зобов'язань за поточною вартістю виконання і пропонує однаковий підхід до оцінки і подання всіх договорів страхування. МСФЗ (IFRS) 17 замінює МСФЗ (IFRS) 4 "Страхові контракти", а також пов'язані з ним інтерпретації і вступає в силу для річних періодів, що починаються 1 січня 2023 року або після цієї дати, 3 можливістю дострокового застосування за умови попереднього застосування МСФЗ (IFRS) 15 «Виручка за договорами 3 клієнтами» i МСФ3 (IFRS) 9 «Фінансові інструменти» [5].

Згідно 3 дослідженнями компанії Willis Towers Watson (WTW), впровадження нового міжнародного стандарту фрінансової звітності страховиків IFRS 17 обійдеться світовій страховій галузі в 20 млрд \$. Нещодавно компанія WTW провела опитування 312 страховиків 3 50 країн напередодні дати вступу в силу МСФ3 (IFRS) 17. Дослідження WTW показало, що середня вартість програми для 24 найбільших транснаціональних корпорацій становить від 175 млн \$ до 200 млн \$ для кожної, і 20 млн \$ для інших 288 страховиків. Хоча передбачувані витрати істотно розрізняються в залежності від розміру страховика, загальна глобальна галузева оцінка загальних витрат на впровадження МСФЗ 17 становить 15-20 млрд \$ [6].

Жорсткі заходи законодавчого регулювання діяльності страхових компаній допоможуть наблизити ринок України до міжнародних стандартів. Вихід з ринку слабких гравців природний процес в кризові часи. 
Ділова діяльність страхових підприємств не $\epsilon$ типовою, їх продукція $€$ ризикованим бізнесом. Ці характеристики вимагають, щоб аудиторські фрірми, які здійснюють аудит фрінансової звітності у страхових підприємствах, були великими та мали високу репутацію. Хоча кількість аудиторських фрірм в Україні за даними Реєстру аудиторів та суб'єктів аудиторської діяльності від 16.06.2021 р. становить 186, лише 81 з них які мають право проводити обов'язковий аудит фрінансової звітності підприємств, що становлять суспільний інтерес, до яких відносяться страхові компанії [1].

Основними законодавчими актами, які регулюють страхову діяльності в Україні, $€$ Закон України «Про фрінансові послуги та державне регулювання ринків фрінансових послуг» та Закон України «Про страхування». Страхова компанія як фрінансова установа, відповідно до Закону України «Про аудит фрінансової звітності та аудиторську діяльність», є суб'єктом обов'язкового аудиту. Відповідно до пункту 1 статті 15 Закону України «Про фрінансові послуги та державне регулювання ринків фрінансових послуг» із метою контролю та нагляду за поточною діяльністю страхової компанії обов'язковим є створення незалежного підрозділу внутрішнього аудиту. Основним нормативно-правовим актом, що встановлює методологію проведення внутрішнього аудиту у страхових компаніях $€$ Розпорядження НацКомФінПослуг від 05.06.2014 № 1772 «Про затвердження Порядку проведення внутрішнього аудиту (контролю) у фрінансових установах». Рекомендації стосуються таких питань як встановлення організаційного статусу служби внутрішнього аудиту страхової компанії, врегулювання діяльності внутрішніми регламентами, координація відносин внутрішнього аудиту із зовнішнім незалежним аудитором, планування діяльності та поточного нагляду.

Відділ внутрішнього аудиту повинен контролювати фрінансову звітність, звіт про рух грошових коштів і процеси розкриття інорормації, як на щорічній, так і на щоквартальній основі. Ефрективне фрункціонування служби внутрішньо-го аудиту $є$ надзвичайно важливим для посилення стабільності страхової компанії, оскільки фрінансова неспроможність страхової компанії стосується інте-ресів значної кількості осіб - і страхувальників, і застрахованих.

Мета внутрішнього аудиту страхової компанії - перш за все контроль та попередження, а також нагляд за дотриманням та якістю виконання контрольних фрункцій керівників, спеціалістів, матеріально відповідальних осіб, співробітників обліку та інших робітників функції контролю. Внутрішній аудит потрібен для забезпечення дієвості системи внутрішнього контролю та запобіганню порушень.

Згідно фрункцій страхової компанії основними завданнями внутрішнього аудиту $\epsilon$ : запобігання страхового шахрайства; есрективність фрункції управління ризиками; достатність формування страхових резерів; резонність актуарного ціноутворення; розмежування коштів акціонерів і власників полісів; управління проміжними рахунками; резонність визнання доходу; компетентність штату; забезпечення відповідності нормативній базі.

Основними об'єктами внутрішнього аудиту $\epsilon$ : аудит страхових премій; аудит страхових виплат; аудит страхових резервів; аудит агентської винагороди; аудит грошових коштів і перевірка банківських операцій.

Метою внутрішнього аудиту доходів та витрат страхової організації $\epsilon$ формування думки про достовірність показників «Звіту про фрінансові результати». В якості джерел аудиторських доказів використовується: звіт про прибутки та збитки; договори страхування, співстрахування, перестрахування; договори оренди; облікова політика, облікові реєстри по рахунках; первинні документи, підтверджуючі доходи.

Внутрішній аудит перевірки обґрунтованості складу доходів по горизонталі дозволяє оцінити, в якій частині із складових доходу відбулися найбільші відхилення (бажані та небажані), які темпи росту та яке співвідношення темпу росту пропорційне до фрормування доходів. Внутрішній аудит перевірки обґрунтованості складу доходів по вертикалі дає можливість скласти профресійну думку про те, яка складова частина має найбільшу питому вагу в загальній сумі доходів.

При внутрішньому аудиті витрат страховика аудитор у першу чергу встановлює обґрунтованість вибуття активів витратами страхової організації. В процесі аудиту важливо встановити правильність відношення витрат до відповідної групи, що відбувається відповідно до основних видів діяльності страховика, передбаченими уставними документами. Процедури аудиту витрат знаходяться в залежності від положень облікової політики, де передбачено: методику нарахування собівартості страхової продукції, порядок розподілу загальновиробничих та адміністративних витрат. Внутрішній аудит витрат проводиться 3 перевіркою обґрунтованості та докумен- 
тального підтвердження витрат, понесених страховиком за умовою, що вони зроблені для ведення діяльності, направленої на отримання доходу. Принципову важливість при цьому має класифрікація витрат.

В якості вихідної інфрормації перевірки обґрунтованості витрат використовуються матеріали горизонтального та вертикального аналізу складу і структури витрат страхової організації.

Внутрішній аудит зобов'язань передбачає перевірку як зобов'язань інших організацій та осіб перед страховою організацією (дебіторська заборгованість), так і зобов'язання страховика перед іншими організаціями та особами (кредиторська заборгованість). Дебіторська заборгованість організації, обґрунтованість якої встановлює аудитор, показується у розрізі строків, протягом яких очікується платежі за її погашення. Мета внутрішнього аудиту зобов'язань - фрормування думки про достовірність показників за статтями бухгалтерського балансу.

Фінансові результати діяльності страхової організації в загальному вигляді представляють різницю доходів та витрат, визнаних страховиком у відповідному порядку. Мета внутрішнього аудиту фрінансових результатів - формування аудитором думки про відношення показників фрінансових результатів звіти про прибутки або збитки. Модель формування чистого прибутку страхової компанії представлена на рис. 2.

При перевірці фрінансової звітності типовими $€$ помилки, пов'язані $з$ неправильною класифрікацією операційних та інвестиційних доходів і витрат. В ході перевірки має місце використання наступних аудиторських процедур: звірка 3 первинними документами; перевірка правильності віднесення витрат на період; аналіз даних, акумульованих на рахунках доходів та витрат.

Ефрективність результатів внутрішнього аудиту компанії залежить від якості взаємодії служби внутрішнього аудиту з іншими фуункціями та підрозділами компанії. Для максимально ефективного виконання своїх функцій служба внутрішнього аудиту має максимально повно та регулярно висвітляти результати проведених перевірок та виявлені недоліки. В табл. 1 представлена модель ефрективної взаємодії служби внутрішнього аудиту з іншими службами компанії.

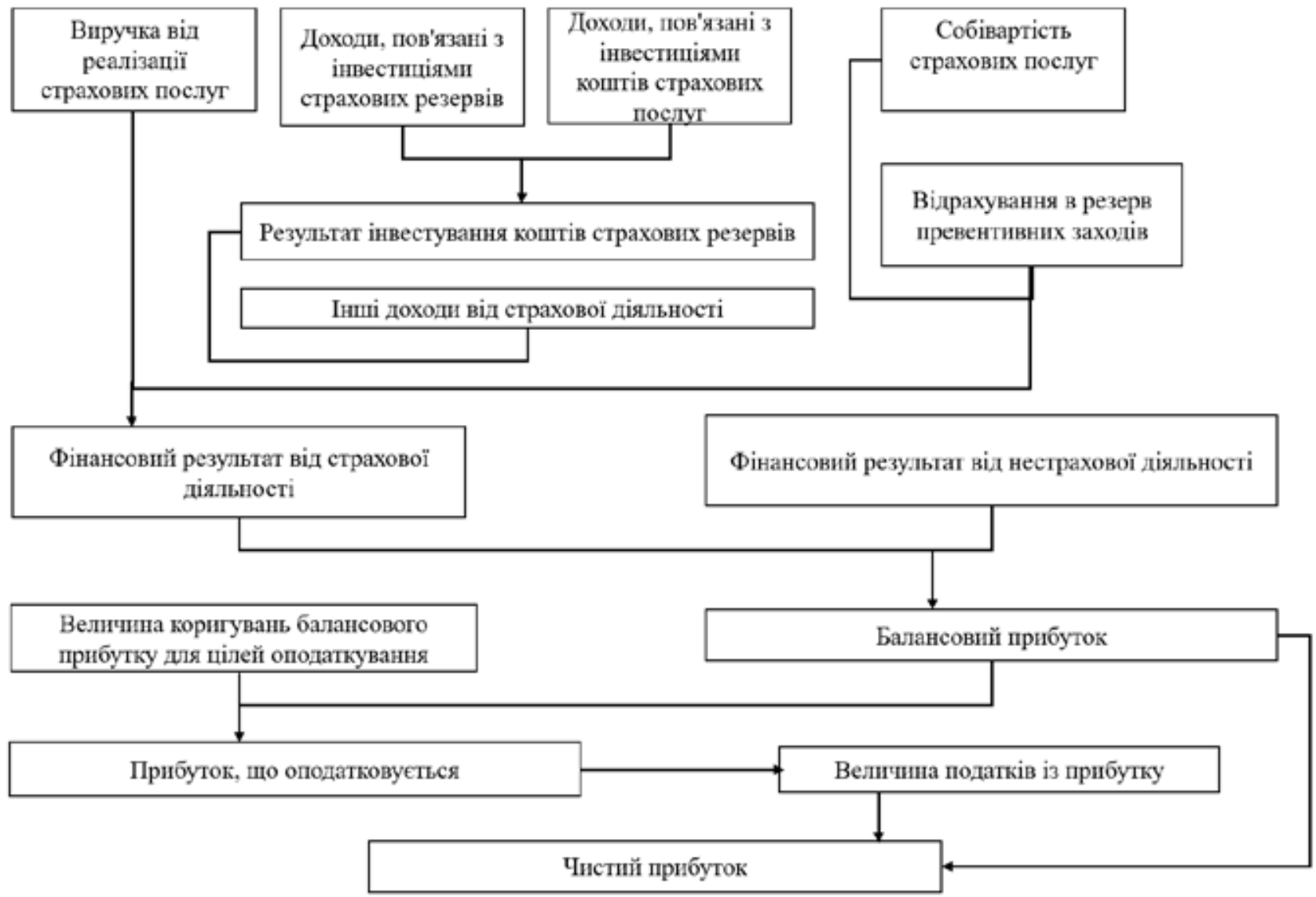

Рис. 2. Модель формування чистого прибутку страхової організації Джерело: [9] 
Труднощі оцінки есрективності роботи служби внутрішнього аудиту страхової компанії пов'язані з різними обставинами:

- складність кількісної оцінки результату;

- ефективність залежить не лише від аудиторів, а й від дій відповідальних підрозділів: наскільки якісно виконуються рекомендації аудиторів.
- суб'єктивізм в оцінці роботи аудиторів 3 боку керівництва компанії.

Окрім недосконалої системи внутрішнього аудиту страхових компаній, «вузьке місце» ринку страхування полягає в відставанні від сучасних технологічних тенденцій. Для страхових компаній характерні наступні інорормаційні та аналітичні проблеми:

\section{Особливості координації служби внутрішнього аудиту з іншими підрозділами страхової компанії [9]}

\begin{tabular}{|c|c|c|}
\hline \begin{tabular}{|c|} 
Взаємодія служби \\
внутрішнього аудиту з \\
іншими службами компанії \\
\end{tabular} & $\begin{array}{c}\text { Основні аудиторські } \\
\text { завдання }\end{array}$ & $\begin{array}{c}\text { Результат внутрішнього } \\
\text { аудиту }\end{array}$ \\
\hline $\begin{array}{l}\text { Служба внутрішнього аудиту } \\
\text { компанії ঙ Керівництво } \\
\text { компанії }\end{array}$ & $\begin{array}{l}\text { Контроль за створенням } \\
\text { достовірної інорормації про } \\
\text { діяльність страхової компанії. }\end{array}$ & $\begin{array}{l}\text { Надання оцінки діяльності } \\
\text { компанії, результатів перевірок } \\
\text { та аналізу; рекомендації } \\
\text { та висновки, підтримка в } \\
\text { реалізації бізнес-цілей. }\end{array}$ \\
\hline $\begin{array}{l}\text { Служба внутрішнього аудиту } \\
\text { компанії ↔ Юридична } \\
\text { служба компанії }\end{array}$ & \begin{tabular}{|l|} 
Забезпечення контролю \\
та оцінка дотримання \\
нормативних актів, внутрішніх \\
політик та правил.
\end{tabular} & $\begin{array}{l}\text { Надання матеріалів по фракту } \\
\text { стягнення дебіторської } \\
\text { заборгованості; актів для } \\
\text { юридичної оцінки негативних } \\
\text { фактів страхової галузі. }\end{array}$ \\
\hline 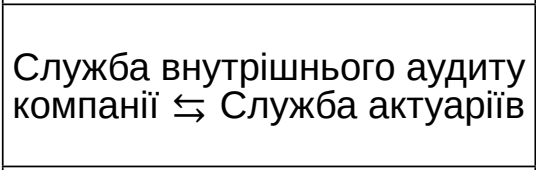 & $\begin{array}{l}\text { Перевірка обґрунтованості } \\
\text { політики ціноутворення на } \\
\text { продукти страхової компанії. }\end{array}$ & $\begin{array}{l}\text { Індикація критичних областей, } \\
\text { що потребують змін; } \\
\text { рекомендації для зниження } \\
\text { ризику шахрайства. }\end{array}$ \\
\hline $\begin{array}{l}\text { Служба внутрішнього } \\
\text { аудиту компанії } \leftrightarrows \text { Служба } \\
\text { ризик-менеджменту та } \\
\text { андерайтингу }\end{array}$ & $\begin{array}{l}\text { Перевірка правильності } \\
\text { оцінки керування ризиками } \\
\text { в страховій та інвестиційній } \\
\text { діяльності. }\end{array}$ & $\begin{array}{l}\text { Оцінка здатності механізмів } \\
\text { внутрішнього контролю } \\
\text { ефрективно здійснювати } \\
\text { спостереження, контролювати } \\
\text { і управляти фрінансовими } \\
\text { ризиками; докладний } \\
\text { огляд потенційного впливу } \\
\text { фінансових ризиків, перевірка } \\
\text { активів, зобов'язань і умовних } \\
\text { зобов'язань по суті. } \\
\end{array}$ \\
\hline 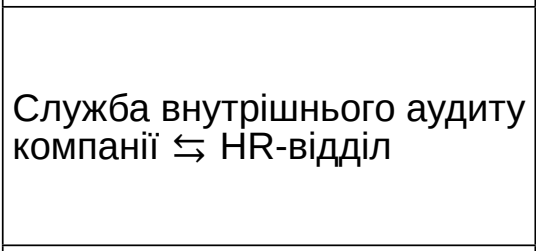 & $\begin{array}{l}\text { Оцінка есрективності } \\
\text { використання людських } \\
\text { ресурсів компанії. }\end{array}$ & $\begin{array}{l}\text { Рекомендації щодо } \\
\text { ефрективного використання } \\
\text { потенціалу та навичок } \\
\text { персоналу; положення по } \\
\text { вдосконаленню оплати праці та } \\
\text { складанню штатних розкладів. } \\
\end{array}$ \\
\hline $\begin{array}{l}\text { Служба внутрішнього аудиту } \\
\text { компанії ↔ Відділ продажу } \\
\text { та маркетингу }\end{array}$ & \begin{tabular}{|l|} 
Перевірка обґрунтованості \\
каналів просування страхових \\
продуктів, оформлення \\
прайс-протоколів; правил \\
надання знижок. \\
\end{tabular} & $\begin{array}{l}\text { Консультації з запуску нових } \\
\text { продуктів і виходу на нові } \\
\text { ринки. }\end{array}$ \\
\hline 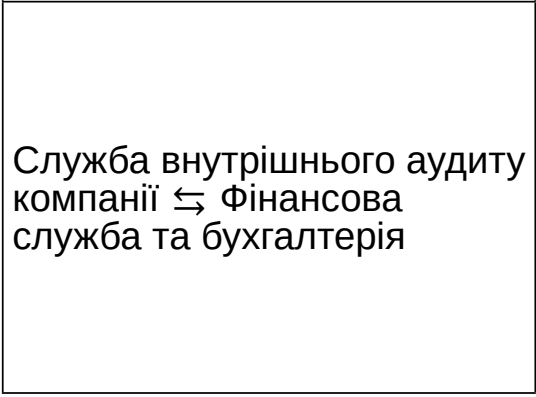 & \begin{tabular}{|l|} 
Оцінка правильності \\
розрахунків та сплати податків, \\
оцінка оптимального вибору \\
режиму оподаткування. \\
Перевірка повноти \\
відображення виручки від \\
продажу страхових продуктів; \\
перевірка повноти та \\
своєчасності врегулювання \\
збитків по страховим випадкам. \\
\end{tabular} & $\begin{array}{l}\text { Надання матеріалів перевірки } \\
\text { та аналізу, інформування про } \\
\text { зміни в законодавстві, обліку } \\
\text { та звітності. }\end{array}$ \\
\hline
\end{tabular}


1) інформаційна непрозорість страхового ринку;

2) низький рівень впровадження сучасних інсрормаційних технологій в практику страхування;

3) відсутність якісної статистичної інорормації і докладних інфрормаційно-аналітичних матеріалів про ситуацію і проблеми фрормування страхового ринку;

4) недосконалі методи формування фрінансової звітності та обробки даних.

Інновації завдяки новим технологіям $€$ ключовим рушієм розвитку у фрінансовому секторі. На фроні пандемії COVID-19, сфрера послуг поступово переїхала на онлайн-платорорму, з можливістю придбати послугу не виходячи з дому. Страховий сектор не $є$ винятком для такого розвитку подій. Можливість імплементації нових методів надання послуг, а також розширення джерел збору даних та виявлення шахрайства, покращить виявлення ризиків та створення заходів їх усунення, що називається "InsurTech".

Такого роду інновації зможуть вплинути на вартість фрраншизи страхових компаній з відповідними вимогами щодо політики конкуренції. Поліси з індивідуальним покриттям і спрощеними процесами розгляду претензій можуть поліпшити охоплення тих верств суспільства, які досі не мали доступу до фрінансової захисту.

На нашу думку, НБУ має впровадити можливість збору гранулярних даних фрінансової звітності із застосуванням сучасних IT-технологій, що дозволить глибше аналізувати і оцінювати ризики страхових компаній, дотримання ними регуляторних вимог, а страховим компаніям оптимізувати витрати на підготовку та подання звітів. Аудит фрінансової звітності страхових компаній і спеціалізованих перестраховиків $€$ важливим доповненням до процесу нагляду за діяльністю страхових компаній.

Ми вважаємо, що цифрові технології $\epsilon$ рушійною силою серйозних змін в страховій галузі. Замість того, щоб інвестувати в повністю нові системи, компанії можуть доповнити успадковані системи обліку модернізованими інструментами, такими як програмне забезпечення для управління бізнес-процесами, онлайн обслуговування клієнтів, хмарні рішення і багато іншого. Консолідація розрізнених успадкованих систем в централізовані платорорми з використанням технологій міграції даних і проектування може знизити витрати на обслуговування і експлуатацію, надаючи переваги повністю оновленої системи. Для комплексного аналізу історичних даних та прогнозування тенденцій страхові компанії повинні використовувати такі види аналітичних даних: дескриптивна аналітика; діагностична аналітика; прогнозна аналітика та пропонуюча аналітика.

Дослідження, проведене в 2018 році компанією Valen Analytics, показало, що компанії, які використовують аналітику і предиктивне моделювання, поліпшили свої коефріцієнти збитковості на 3\%-9\% в порівнянні 3 компаніями, які цього не робили. Страховики, які використовують предикативну аналітику, збільшили свої прямі страхові премії на 53\%, в порівнянні із середньо ринковими зростанням на $18 \%$ за той же період часу [10].

У страхових компаніях необхідне впровадження ефективної системи внутрішнього контролю ризиків порушення платоспроможності, і тим більше, ризиків порушення ліквідності, що сприятиме їх нейтралізації на початковій стадії. Успішне фрункціонування страхової організації неможливо без забезпечення ефрективного контролю, що дозволяє менеджменту компанії отримувати необхідну і достовірну інформацію для прийняття управлінських рішень. Для оцінки орінансової стійкості страхової організації система внутрішнього контролю повинна здійснювати постійний моніторинг відповідності параметрів і вимог, на основі яких розроблена модель системи внутрішнього контролю і аудиту страхових організацій, спрямована на превентивну діагностику ризиків страховика.

Впровадження моделі безперервного внутрішнього аудиту вимагає значних зусиль на перших етапах. Це процес, який впроваджується паралельно зі зрілістю аудиторської срункції всередині компанії. Початкові цілі проекту зосереджені на розробці моделі та впровадженні процесів для виявлення і аналізу закономірностей, виявлення аномалій і вилученні іншої корисної інформації з даних.

Модель імплементації системи безперервного внутрішнього аудиту може складатися 3 наступних кроків:

1. Виявлення пріоритетних напрямів страхування.

2. Визначення правил аудиту.

3. Встановлення частоти процесу.

4. Налаштування параметрів і виконання.

5. Управління і моніторинг результатів.

6. Інсрормування про результати.

7. Оцінка і поповнення реєстру можливих ризиків.

Результати проведеного дослідження мають бути центром співпраці між внутрішнім 
та зовнішнім аудитом у страхових компаніях. Принципи та обсяг співпраці між внутрішнім та зовнішнім аудитом вимагають розробки певних передових практик, які обов'язково втіляться з часом - внутрішній аудит є відносно недавнім механізмом контролю у страхових організаціях, і як методологія його роботи, так і значення все ще в процесі становлення.

Слід підкреслити, що цілі внутрішнього аудиту відрізняються від цілей зовнішнього аудиту, який визначається як фрінансовий аудит. Поза всяким сумнівом, така співпраця корисна як з точки зору внутрішнього, так і зовнішнього аудиту, оскільки може полегшити цілі аудиту та сприяти підвищенню ефективності відповідних механізмів контролю.

щоб зберегти свою життєздатність в майбутньому, страхова галузь повинна розвиватися. Результат ризиків не може бути повністю відомий, але ідентиорікація, оцінка та управління ними мають істотне значення для успіху страховиків. Для ефрективного фрункціонування необхідно краще розуміти тенденції страхової індустрії і потреби споживачів.

Висновки. Недостатнє розуміння ризиків в галузі, невизначеність вимог до капіталу і недостатня прозорість і порівнянність фрінансової звітності підсилюють проблеми, з якими в своїй діяльності стикаються страхові компанії.

Аудит фрінансової звітності страхових компаній і спеціалізованих перестраховиків $\epsilon$ невід'ємним елементом нагляду за діяльністю страхових компаній. Законодавство зобов'язує страховиків не тільки проводити перевірку своїх облікових політик та рахунків експертними аудиторами (зовнішній - фрінансовий аудит), а й впроваджувати комітети 3 внутрішнього аудиту. Внутрішній аудит, безсумнівно, є дуже важливим механізмом контролю ефективності для страхових компаній, адже він підтримує і регулює управлінські процеси, зокрема, в галузі фрінансів, бухгалтерського обліку та управління ризиками.

У страхових компаніях необхідне впровадження ефективної системи внутрішнього контролю ризиків порушення платоспроможності, і тим більше, ризиків порушення ліквідності, що сприятиме їх нейтралізації на початковій стадії. Успішне фрункціонування страхової організації неможливо без забезпечення ефрективного контролю, що дозволяє менеджменту компанії отримувати необхідну і достовірну інформацію для прийняття управлінських рішень. Для оцінки фрінансової стійкості страхової організації система внутрішнього контролю повинна здійснювати постійний моніторинг відповідності параметрів і вимог. Одним з ключових моментів оптимізації діяльності страхових організацій $€$ налагодження співпраці між внутрішнім і зовнішнім аудитом головним чином в області взаємного спілкування і обміну досвідом, а також планування аудиторських перевірок.

Згодом форми взаємодії цих механізмів контролю і спектр інструментів контролю будуть розширюватися. Точно визначити напрямки цих змін складно, оскільки вони будуть залежати від мінливих реалій і нових видів ризиків, що загрожують діяльності страхового бізнесу. Це узгоджується 3 ідеєю і метою внутрішнього аудиту, який повинен бути адаптований під постійний процес змін, щоб ефрективно підтримувати процес управління ризиками в страховій компанії. Впровадження цих механізмів контролю для підтримки процесів управління ризиками в страхових компаніях забезпечує розвиток співпраці з метою підвищення ефективності, скорочення трудовитрат на проведення аудиторських перевірок, поліпшення управління ризиками, пов'язаними з діяльністю страхових компаній.

\section{СПИСОК ВИКОРИСТАНИХ ДЖЕРЕЛ:}

1. Пресслужба «Національної комісії, що здійснює державне регулювання у сфрері ринків фрінансових послуг». URL: https://www.nfp.gov.ua/

2. Реєстр показників звітності небанківських фінансових установ. 2021. URL: https://bank.gov.ua/ua/statistic/ nbureport/statreport-nonbanking

3. Біла книга «Майбутнє регулювання ринку страхування в Україні» // Національний банк України. 2020. URL: https://bank.gov.ua/admin_uploads/article/White_paper_insurance_2020.pdf?v=4

4. IFRS 17 and Solvency II // SAS ${ }^{2}$ GLOBAL FORUM 2021. 2021. URL: https://www.sas.com/en_lu/insights/ articles/risk-fraud/ifrs4-and-solvency2.html

5. The IFRS ${ }^{2}$ Foundation // International Accounting Standards Board. 2021. URL: https://www.ifrs.org/

6. Willis Towers Watson Solutions // Willis Towers Watson. 2021. URL: https://www.willistowerswatson.com/

7. Global Insurers Face Hefty Costs of \$15B-\$20B to Implement IFRS 17: WTW // Insurance journal. 2021. URL: https://www.insurancejournal.com/news/international/2021/06/08/617807.htm 
8. Insurance Audit Services // Enterslice Award Winning Legal Technology \& CPA firm. 2021. URL: https://enterslice.com/insurance-audit

9. Нікуліна Н. Н. Практичний страховий аудит. Москва: Юнити, 2015. 286 с.

10. Valen Analytics InsureRight Platform. URL: https://www.insurity.com/solutions/insurity-data-analyticssolutions/valen-analytics-insureright-platform/

11.Закон України «Про аудит фрінансової звітності та аудиторську діяльність». URL: https://zakon.rada.gov.ua/ laws/show/2258-19\#Text

\section{REFERENCES:}

1. Pressluzhba "Natsionalnoi komisii, shcho zdiisniuie derzhavne rehuliuvannia u sferi rynkiv finansovykh posluh" (2021). Available at: https://www.nfp.gov.ua/

2. Reiestr pokaznykiv zvitnosti nebankivskykh finansovykh ustanov (2021). Available at: https://bank.gov.ua/ua/ statistic/nbureport/statreport-nonbanking

3. Bila knyha "Maibutnie rehuliuvannia rynku strakhuvannia v Ukraini" // Natsionalnyi bank Ukrainy. 2020. Available at: https://bank.gov.ua/admin_uploads/article/White_paper_insurance_2020.pdf?v=4

4. IFRS 17 and Solvency II // SAS® GLOBAL FORUM 2021 (2021). Available at: https://www.sas.com/en_lu/ insights/articles/risk-fraud/ifrs4-and-solvency2.html

5. The IFRS ${ }^{\circledR}$ Foundation // International Accounting Standards Board. 2021. Available at: https://www.ifrs.org/

6. Willis Towers Watson Solutions // Willis Towers Watson. 2021. Available at: https://www.willistowerswatson.com/

7. Global Insurers Face Hefty Costs of \$15B-\$20B to Implement IFRS 17: WTW // Insurance journal. 2021. Available at: https://www.insurancejournal.com/news/international/2021/06/08/617807.htm

8. Insurance Audit Services // Enterslice Award Winning Legal Technology \& CPA firm (2021). Available at: https://enterslice.com/insurance-audit

9. Nikulina N.N. (2015) Praktychnyi strakhovyi audyt. Moscow: Yunyty, 286 p.

10. Valen Analytics InsureRight Platform (2021). Available at: https://www.insurity.com/solutions/insuritydata-analytics-solutions/valen-analytics-insureright-platform/

11. Zakon Ukrainy "Pro audyt finansovoi zvitnosti ta audytorsku diialnist". Available at: https://zakon.rada.gov.ua/ laws/show/2258-19\#Text 